\title{
Spreading of the invasive dinoflagellate Ceratium furcoides (Levander) Langhans throughout the Paraiba do Sul ecoregion, South America, Brazil
}

\author{
Rafael Lacerda Macêdo ${ }^{1,2, *}$ iD, Ana Clara Sampaio Franco ${ }^{2}$, Raphael Ferreira Corrêa ${ }^{1}$, Karen \\ do Nascimento Costa ${ }^{1}$, Laryssa Gonçalves Pereira ${ }^{1}$, Fernanda Daniela Maniero de Oliveira ${ }^{1}$, \\ Gabriel Klippel ${ }^{1}$, Bruno Damasceno Cordeiro ${ }^{2}$, Mariana Guedes Ribeiro Thiago ${ }^{1}$, Maria \\ Isabel de A. Rocha ${ }^{1}$, Vera L. M. Huszar ${ }^{3}$, Luciano Neves dos Santos ${ }^{2}$ and Christina Wyss \\ Castelo Branco ${ }^{1,2}$
}

1 Núcleo de Estudos Limnológicos; Universidade Federal do Estado do Rio de Janeiro (UNIRIO), Av. Pasteur, 458, 22290-240. Rio de Janeiro, RJ, Brasil.

2 Laboratório de Ictiologia Teórica e Aplicada, Universidade Federal do Estado do Rio de Janeiro (UNIRIO), Av. Pasteur, 458 - R314A, 22290-240. Rio de Janeiro, RJ, Brasil.

${ }^{3}$ Laboratório de Ficologia, Museu Nacional, Universidade Federal do Rio de Janeiro (UFRJ), Quinta da Boa Vista, Horto Botânico, 20940-040, Rio de Janeiro, RJ, Brasil.

* Corresponding author: rafaell261@hotmail.com

Received: 31/01/20

Accepted: 19/06/20

\begin{abstract}
Spreading of the invasive dinoflagellate Ceratium furcoides (Levander) Langhans across Paraiba do Sul ecoregion, South America, Brazil: reservoirs on warning

The proliferation of the freshwater dinoflagellate Ceratium furcoides (Levander) continues to escalate within South America. Early detection and the subsequent monitoring of this non-indigenous species are essential mitigation polices in the basins at potential risk. A combination of these policies with a better understanding of the dinoflagellate's environmental habitat would thus, assist in reducing possible impacts on the highly diverse aquatic biodiversity of this region. The invasive dinoflagellate can now be found in the tropical reservoirs of three hydroelectric power plants, which extends its presence over a distance of $\sim 500 \mathrm{~km}$ along the Paraíba do Sul eco-region in southeastern Brazil. Less than favorable water management strategies between river basins have probably accelerated this expansion. Water residence time has also most likely influenced the presence and abundance of $C$. furcoides. The smallest recorded size of $C$. furcoides reported in the literature (51-68 $\mu \mathrm{m}$ length, 14-16 $\mu \mathrm{m}$ width) was detected in the reservoir with the lowest water residence time, this indicates a probable adaptation of this invader to water current. The variety of environmental conditions in which $C$. furcoides was found reinforces the assumption that it is a highly eurytopic species. Despite there being no evidence of blooms, the invasiveness of $C$. furcoides suggests that other nearby aquatic systems throughout Paraíba do Sul and Guandu river basins may indeed already harbor populations of $C$. furcoides. This scenario heightens the urgency to formulate a monitoring program with an integrated and predictive approach on a regional scale as millions of people depend economically upon these river systems and importantly, for water supply.
\end{abstract}

Key words: aquatic invasion, dinoflagellate, reservoirs, plasticity, water residence time

\section{RESUMO}

Expansão do dinoflagelado invasor Ceratium furcoides (Levander) Langhans sobre a ecorregião Paraíba do Sul, América do Sul, Brasil: reservatórios em alerta

A distribuição não nativa de Ceratium furcoides está se expandindo na América do Sul. A detecção precoce e o rastreio desse dinoflagelado bem como o aprimoramento do conhecimento sobre seus requisitos ambientais são essenciais estratégias de 
mitigação em bacias potencialmente ameaçadas. Tais ações de mitigação, combinadas ao conhecimento dos requisitos ambientais desse dinoflagelado, podem auxiliar na redução de possíveis impactos à biodiversidade aquática, altamente diversificada, desta região. Este dinoflagelado invasor alcançou três reservatórios tropicais, estendendo sua ocorrência por mais de $500 \mathrm{~km}$ ao longo da ecorregião Paraiba do Sul, no sudeste do Brasil. O gerenciamento artificial entre bacias hidrográficas pode ter acelerado a expansão da distribuição na região. O tempo de residência da água provavelmente exerce um importante papel influenciando a presença e a abundância de C. furcoides. $O$ menor comprimento de C. furcoides relatado na literatura (51-68 $\mu \mathrm{m}$ e 14-16 $\mu \mathrm{m}$, respectivamente para comprimento e largura) foi detectado no reservatório com o menor tempo de residência, indicando uma provável adaptação desse invasor à ambientes mais lóticos. A variedade de condições ambientais em que C. furcoides foi encontrado o reforça como uma espécie altamente euritópica. Apesar de não haver evidências de florações, a capacidade de dispersão de C. furcoides permitem prever que outros sistemas aquáticos nas proximidades das bacias dos rios Paraiba do Sul e Guandu já possam abrigar populações de C. furcoides. Esse cenário suscita preocupação em escala regional, uma vez que diversas atividades econômicas e abastecimento de água para milhões de pessoas dependem desse sistema de rios.

Palavras chave: invasão aquática, dinoflagelados, reservatórios, plasticidade, tempo de residência

\section{INTRODUCTION}

Invasive species pose a continued threat to freshwater biodiversity especially in those dedicated human modified ecosystems, such as reservoirs (Johnson et al., 2008). These artificial systems prove to be more prone to biological invasion and often act as "stepping-stones" for the proliferation of invasive species (Havel et al., 2005a). In particular, the structure of plankton assemblages in recently impounded waterways indicate strong shifts favored by an increase in water retention time, temperature and transparency (Branco et al., 2019). Furthermore, several planktonic species could quickly invade new habitats (Shurin, 2000) by responding to high ecological plasticity due to features such as high rates of reproduction and adaptability (Litvinchuk et al., 2001), asexual reproduction; thus resulting in colonization from either a single or a few individuals (Dodson \& Frey, 2001) and further to this, under propagule pressure, as resting eggs and cysts permit planktonic organisms to exploit a number of potential dispersal vectors (Havel \& Shurin, 2004; Genitsaris et al., 2011).

Moreover, the number of established non-native species is much higher in the tropics than in temperate zones (Sax, 2001) which has now also increased emerging threats to freshwater biodiversity (Reid et al., 2019). In tropical regions such as Latin America and the Caribbean, those freshwater ecosystems that harbor a rich and unique biodiversity must currently contend with severe multiple threats of widespread damming, mining, agriculture, overfishing, contamination, aquaculture, climate change and the introduction of alien species (UNEP, 2010). As man-made infrastructure, water impoundments are constructed for multiple purposes such as water supply and hydropower generation. This also produces a flow-on effect thus influencing ecohydrological dynamics such as fish migration, river flow, riverine habitats, and the proliferation of alien species along river basins (Freeman et al., 2002; Liermann et al., 2012; Xiong et al., 2018). The sum of such various threats could indeed magnify a series of negative effects on aquatic ecosystems. Contained within this list of prospective threats is the rise in number of dams projected for construction in the near future (Anderson et al., 2018; Pereira et al., 2017).

Surprisingly, microorganisms are seldom recorded as invasive, in comparison to macroscopic organism, this due to difficulties in detection and accurate identification (Lebret et al., 2013). In relation to small planktonic species, to detect novel populations does require considerable numerical density; as such, their detection suggests some effective dispersal or colonization. Among freshwater phytoplankton, the diatom Didymosphenia geminate Lyngbye, the cyanobacteria Raphidiopsis (Cylindrospermopsis) raciborskii Woloszynska and Aphanizomenon (Chrysosporum) ovalisporum Forti, and the dinoflagelate Ceratium furcoides Levander are recognized as key examples of invasive species (Costa et al., 2017; Crossetti et al., 2019). 
Several authors have documented (Mac Donagh et al., 2005; Boltovskoy et al., 2013; Cavalcante et al., 2013; Crossetti et al., 2019; Roriz et al., 2019), the recent invasion by species of the genus Ceratium into South America. Originally recorded in European lakes, Ceratium furcoides Levander (Langhans 1925) is now acknowledged as a global invasive species over a broad-spectrum of latitudinal and longitudinal range, from England down to New Zealand and from Korea across to Canada (Meichtry-de-Zaburlín et al., 2016; Silva et al., 2012; Silva et al., 2018). During the last decade C. furcoides has been spreading rapidly across the South American continent: Argentina (Meichtry-de-Zaburlín et al., 2014), Bolivia (Morales, 2016), Colombia (Ramírez-R et al., 2005; Bustamante Gil et al., 2012), Chile (Almanza et al., 2016), Paraguay (Meichtry-de-Zaburlín et al., 2014), Uruguay (Meichtry-de-Zaburlín et al., 2016;), and Brazil (Santos-Wisniewski et al., 2007; Cavalcante et al., 2013; Cassol et al., 2014; Moreira et al., 2015; Roriz et al., 2019; this study). All of the above countries were considered to be equally susceptible to invasion by $C$. furcoides (Meichtry-de-Zaburlín et al., 2016).

Whilst non toxic, Ceratium spp. can impair water quality (Matsumura-Tundisi et al., 2010) and produce difficulties for water treatment, reducing coagulation, sedimentation and increase clogging (Van Ginkel et al., 2001; Ewerts et al., 2014). A bloom of $C$. furcoides has recently been associated to a mass fish kill in a Bolivian reservoir (Morales, 2016). According to the author, the fish kill was caused by the reduction of available oxygen either associated to a decomposition of the biomass after $C$. furcoides' population collapse or due to night breathing by a large number of this dinoflagellate. Thus, it becomes essential to detect and better understand the distribution patterns of $C$. furcoides within South America with much more awareness of its ecology and environment requirements in order to mitigate any possible impact on this continent's highly diverse aquatic biodiversity.

Provided herein are new occurrences of Ceratium furcoides in a suite of connected reservoirs of different limnological features across the Paraiba do Sul ecoregion. The major morphologi- cal features related to species taxonomic identification and plasticity are briefly addressed.

\section{MATERIAL AND METHODS}

\section{Study area}

This study was conducted in three reservoirs of the Paraiba do Sul River Basin, which encompasses portions of the states of Minas Gerais, São Paulo and Rio de Janeiro, totaling an area of $57000 \mathrm{~km}^{2}$. Paraiba do Sul is the principal river in the Southeast Atlantic Hydrographic province and is largely dammed along its course. Section of its waterflow has been diverted through a set of pumped-storage reservoirs to increase water provision of the Guandu River basin, which services agricultural and industrial activity, hydropower generation, as well as domestic supply for a population of 14.2 million people (CEIVAP, 2020), including the second largest metropolitan region of Brazil (Rio de Janeiro). Santa Branca Reservoir (SBR) is in the upper stretch of the Paraíba do Sul River, very near to the Paraibuna Reservoir, being the upstream and largest dam within this river. Ilha dos Pombos Reservoir (IPO) is situated between the middle-lower and lower reaches of Paraíba do Sul River, after the water diversion to the Guandu River. Despite sharing the same river, the SBR and IPO reservoirs are approximately $450 \mathrm{~km}$ apart. Vigário (VIG), being the third reservoir in our study, receives water diverted from the Paraíba do Sul River, which connects this last river to the Guandu River Basin (Fig. 1). VIG Reservoir as such is, geographically located between the SBR ( 218 km apart) and the IPO ( 159 km) reservoirs. The SBR Reservoir presents the largest surface area $\left(27.2 \mathrm{~km}^{2}\right)$ and water retention time (62 days). Both the VIG and the IPO reservoir are smaller and with lower retention time, being, 3.3 and $4.26 \mathrm{~km}^{2}$, and 2.0 and 0.2 days, respectively.

\section{Sampling and laboratory analysis}

Quantitative plankton samples and environmental variables were collected from surface layers at the three reservoirs during summer (December) 


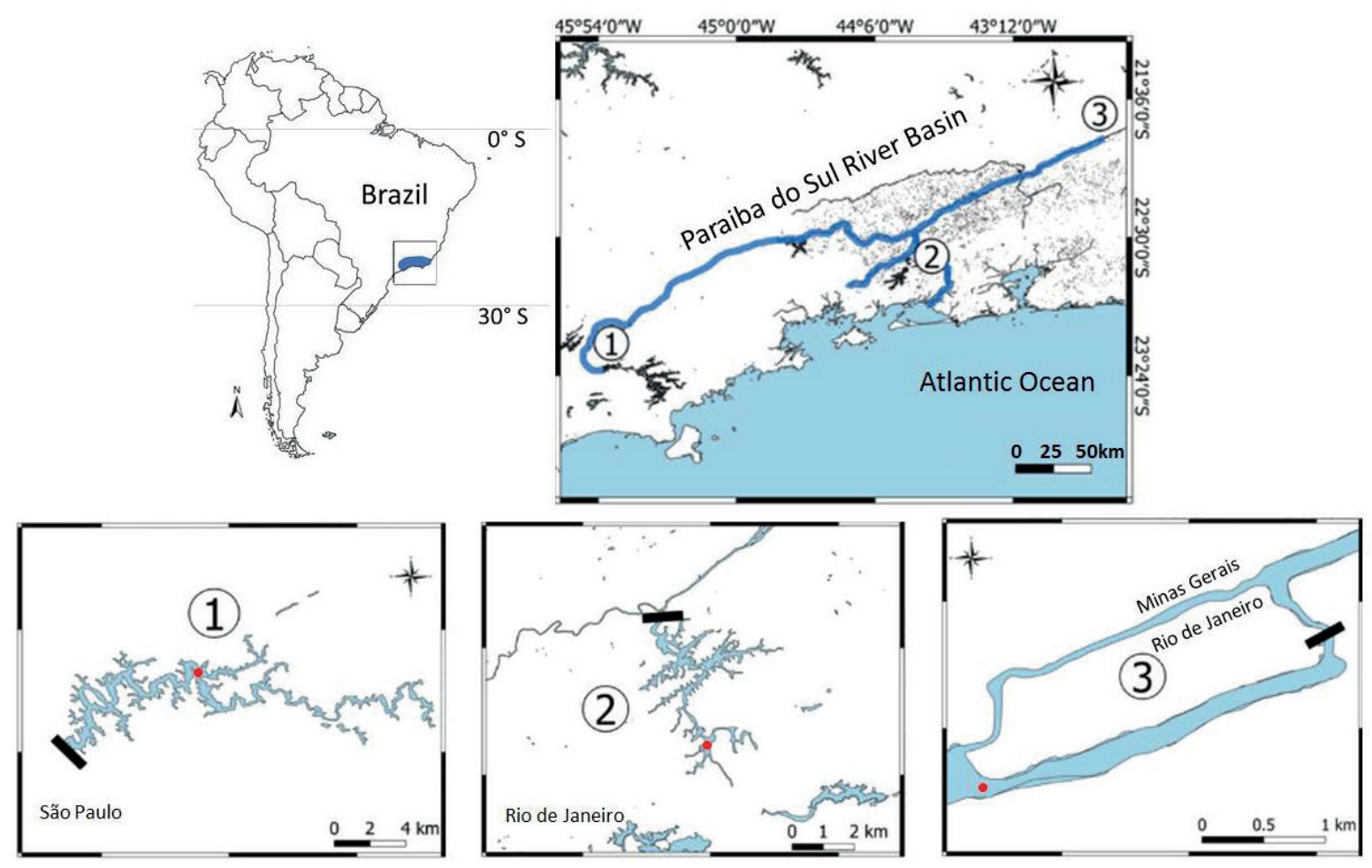

Figure 1. Map showing the Paraíba do Sul River Basin in southeast Brazil and the studied reservoirs from the upstream Santa Branca, the middle-positioned Vigário Reservoir that receives diverted waters and the downstream Ilha dos Pombos Reservoir. Red dots depict sampling sites where $C$. furcoides were found. Black lines represent dams. Coordinates where $C$. furcoides were found: (1) SBR $23^{\circ}$

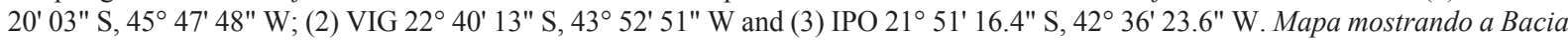
do Rio Paraíba do Sul no sudeste brasileiro e cada reservatório, do mais a montante (Santa Branca), o intermediário Vigário que recebe águas transpostas, e o mais a jusante Ilha dos Pombos. Em vermelho, os pontos onde Ceratium furcoides foi encontrado. Barras pretas representam as barragens dos reservatórios. Pontos vermelhos representam locais onde C. furcoides foi encontrado: (1) $\operatorname{SBR} 23^{\circ} 20^{\prime} 03^{\prime \prime} \mathrm{S}, 45^{\circ} 47^{\prime} 48^{\prime \prime} \mathrm{O}$; (2) $\mathrm{VIG} 22^{\circ} 40^{\prime} 13^{\prime \prime} \mathrm{S}, 43^{\circ} 52^{\prime} 51^{\prime \prime} \mathrm{O}$ and (3) IPO $21^{\circ} 51^{\prime} 16.4^{\prime \prime} \mathrm{S}, 42^{\circ} 36^{\prime} 23.6^{\prime \prime} \mathrm{O}$.

and winter (July), from 2011 to 2014. In addition, qualitative plankton samples were taken by vertical hauls along the euphotic layer using a plankton net of $68 \mu \mathrm{m}$ mesh and $20 \mathrm{~cm}$ diameter. The euphotic layer depth was estimated as Secchi depth multiplied by 2.7 in accordance with Esteves (2011). The number of sampling stations varied according to area size of reservoir being four from the SBR Reservoir, three from VIG and two from IPO. Physical and chemical variables (water temperature, dissolved oxygen, electrical conductivity and $\mathrm{pH}$ ) were measured in situ with a YSI ${ }^{\circledR} 85$ multiparameter probe. Chlorophyll- $a$ was determined by extraction in heated $\left(70-75^{\circ} \mathrm{C}\right)$ $90 \%$ ethanol - following Nusch \& Palme (1975). Water transparency was measured by the Secchi disk depth and turbidity by the INSTRUTHERM TD300 turbidimeter. Collected water samples were filtered through Whatman GF/C filters and then frozen for total alkalinity and dissolved nutrient concentrations analysis in accordance with APHA (2005). Plankton samples were immediately fixed with Lugol-acetic acid. Phytoplankton species counts conformed to Utermöhl (1958) by applying an inverted microscope Axiovert 10 (Zeiss Oberkochen) with $400 \times$ magnification. Cells were enumerated, for at least $100 \mathrm{spec}-$ imens of the most frequent taxa (Lund et al., 1958). Biomass was estimated by employing specific biovolume calculations in line with Rocha \& Duncan (1985). Specific biovolume was estimated from the product of abundance and 
each species mean cell volume. The population carbon content was estimated by multiplying the population density and the mean carbon content of $C$. furcoides.

\section{Data analysis}

Morphological measurements of $C$. furcoides were taken from qualitative samples. Cell length and width were expressed as total mean, minimum and maximum values $(\mathrm{N}=21)$ and compared between reservoirs via analysis of variance (ANOVA). Ceratium specimens were photographed under a Scanning Electron Microscopy AURIGA 40 - ZEISS (Work distance $=4.4 \mathrm{~mm}$ and $1.55 \mathrm{~K} \times$ magnification) to avoid misidentification. Toledo's (1983) Trophic State Index (TSI) was applied to estimate the degree of eutrophication within each reservoir. Water temperature, dissolved oxygen (DO), alkalinity (Alk), turbidity, electric conductivity (Cond), nitrite, total phosphorus (TP), chlorophyll- $a$ and $\mathrm{pH}$ were included in this analysis.

\section{RESULTS}

Populations of Ceratium furcoides were found for the first time in winter samples, concurrently in the three reservoirs of the Paraiba do Sul River.
Electron microscopic photographs (Fig. 2) confirmed the identification of Ceratium furcoides, as plate 4" never extends to the apex in this species (Hickel, 1988; Moestrup \& Calado, 2018), being the main morphological distinctiveness between this species and C. hirundinella. In the SBR Reservoir, the invader was also detected in the winters of 2011 and 2013 and in the summer of 2014 in a single sampling point while in VIG and IPO it was only discovered in 2011 and then went undetected in subsequent years.

Populations of Ceratium furcoides inhabit across a broad range of water temperature, dissolved oxygen, $\mathrm{pH}$, turbidity, nitrate and total phosphorus (Table 1). In all reservoirs $C$. furcoides were detected in sites afar from the dam and displaying low densities (from 26 to $63 \mathrm{ind} / \mathrm{mL}$ ). Although no blooms of this dinoflagellate were uncovered during the study period, a significant variation of $C$. furcoides contribution to total phytoplankton biomass - along a duration of time was noted in the SBR Reservoir. The contribution of $C$. furcoides to the total phytoplankton biomass in this reservoir varied from $8.9 \%$ in the winter of 2011 to $81.9 \%$ within the same season in 2012 . In the VIG Reservoir, C. furcoides accounted for $1.5 \%$ of total phytoplankton biomass, whereas in the IPO, C. furcoides constituted $19.6 \%$ of total biomass.

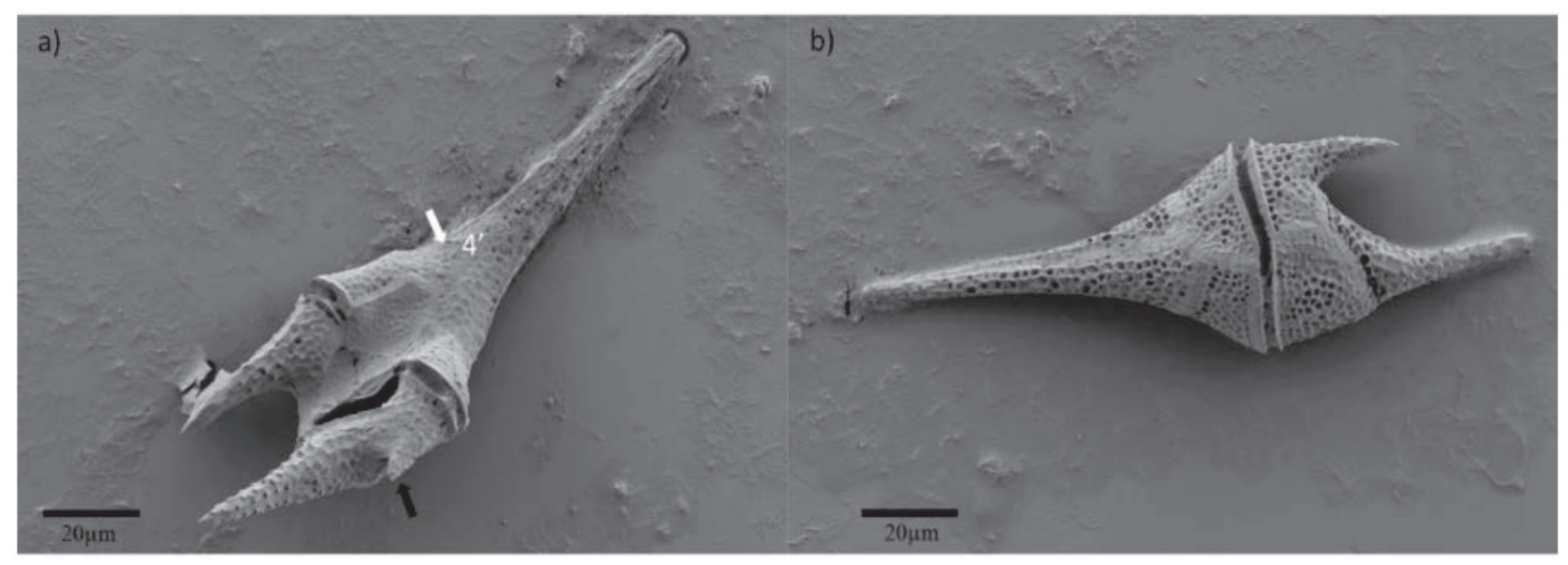

Figure 2. Electromicrography (SEM) of Ceratium furcoides from Santa Branca Reservoir: a) Ventral view showing Plate 4' (white arrow), with the third antapical horn (black arrow) - phenotypic plasticity; b) Dorsal view. Scale bars $=20 \mu \mathrm{m}$. Eletromicrografia (MEV) do Ceratium furcoides coletado no Reservatório de Santa Branca: a) Vista ventral mostrando a $4^{\circ}$ placa (seta branca), com o terceiro chifre anti-apical (seta preta) - suposta plasticidade fenotípica; b) Vista dorsal. Barra de escala $=20 \mu \mathrm{m}$. 
Table 1. Mean values of limnological variables and trophic state of the sites where $C$. furcoides was found. Trophic state classifications according to Toledo et al. (1983): Oligotrophic $24<\mathrm{TSI} \leq 44$, Mesotrophic $44<\mathrm{TSI} \leq 54$, Eutrophic $54<\mathrm{TSI} \leq 74$, and Hypereutrophic TSI $>74$. Relative biomass $\mu \mathrm{g} \mathrm{C/1} \mathrm{( \% )} \mathrm{by} \mathrm{major} \mathrm{phytoplankton} \mathrm{systematic} \mathrm{groups} \mathrm{and} \mathrm{total} \mathrm{density} \mathrm{for} \mathrm{the} \mathrm{sampling} \mathrm{sites} \mathrm{and}$ year where Ceratium furcoides were found. Valores médios das variáveis limnológicas e estado trófico dos pontos onde Ceratium furcoides foi amostrado. Classificação trófica segundo Toledo et al. (1983): Oligotrófico $24<$ TSI $\leq 44$, Mesotrófico 44 < TSI $\leq 54$, Eutrófico $54<T S I \leq 74$, e Hipereutrófico TSI $>74$. Biomassa relativa $\mu \mathrm{g}$ C/l (\%) por grandes grupos sistemáticos do fitoplâncton e densidade total por ponto e ano onde Ceratium furcoides foi encontrado.

\begin{tabular}{lccccc}
\hline \multicolumn{1}{c}{ Variables } & $\begin{array}{c}\text { SBR (2011) } \\
\text { winter }\end{array}$ & $\begin{array}{c}\text { SBR (2013) } \\
\text { winter }\end{array}$ & $\begin{array}{c}\text { SBR (2014) } \\
\text { summer }\end{array}$ & $\begin{array}{c}\text { VIG (2011) } \\
\text { winter }\end{array}$ & $\begin{array}{c}\text { IPO (2011) } \\
\text { winter }\end{array}$ \\
\hline Temperature $\left({ }^{\circ} \mathrm{C}\right)$ & 19.6 & 20.8 & 30.24 & 21.5 & 20.3 \\
Dissolved oxygen $(\mathrm{mg} / \mathrm{l})$ & 6.89 & 5.43 & 8.55 & 3.2 & 6.83 \\
Conductivity $(\mu \mathrm{S} / \mathrm{cm})$ & 29.2 & 31.5 & 45 & 81.5 & 57 \\
Turbidity $(\mathrm{NTU})$ & 2.2 & 1.56 & 2.2 & 6.92 & 8.96 \\
Water transparency $(\mathrm{m})$ & 2.75 & 3.30 & 1.60 & 1.25 & 1.5 \\
pH & 5.6 & 6.79 & 8.99 & 6.5 & 7.9 \\
Orthophosphate $(\mathrm{mg} / \mathrm{l})$ & 0.02 & 0 & 0.01 & 0.04 & 0.04 \\
Total phosphorus $(\mathrm{mg} / \mathrm{l})$ & 0.03 & 0.03 & 0.02 & 0.07 & 0.08 \\
Ammonium $(\mathrm{mg} / \mathrm{l})$ & 0.01 & 0 & 0.02 & 0.13 & 0.01 \\
Nitrite $(\mathrm{mg} / \mathrm{l})$ & 0.02 & 0 & 0.03 & 0.12 & 0.1 \\
Nitrate $(\mathrm{mg} / \mathrm{l})$ & 0.17 & 0.89 & 0.35 & 4.37 & 6.47 \\
Chlorophyll- $a(\mu \mathrm{g} / \mathrm{l})$ & 1.48 & 0.65 & 1.6 & 0.74 & 0.74 \\
Trophic State $\mathrm{Index}$ & 40.39 & 30.95 & 40.31 & 51.65 & 52.28 \\
Mean euphotic zone $(\mathrm{m})$ & 8.1 & 8.9 & 4.3 & 2.02 & 3.4 \\
Relative biomass $\mu \mathrm{gC} / \mathrm{l}(\%)$ & 8.9 & 81.9 & 38 & 1.5 & 19.5 \\
Density (ind/ml) & 63 & 52 & 30 & 26 & 36 \\
\hline
\end{tabular}

Whilst downstream from the SBR, we found a gradient of increasing turbidity and high concentrations of nitrate and total phosphorus. As a result, samples from the VIG and IPO reservoirs mostly correlated to high values of turbidity, and nutrient concentrations. Samples in which cells had been detected also corresponded with a wide range of $\mathrm{pH}$ and dissolved oxygen. The SBR Reservoir was mostly associated to the greatest multiple variation, which also presented separate samples from different seasons and years. These findings revealed the large environmental variability among the conditions in which this species inhabited.

Increases in turbidity and nutrient content in the VIG and IPO reservoirs confirmed the gradient of eutrophication from upstream to downstream Paraíba do Sul River, to include the Trophic State Index (TSI). Nitrogen content recorded more significant degree of difference from upstream reservoir to downstream. According to the TSI, the SBR Reservoir was recognized as being oligotrophic while the two other reservoirs were mesotrophic.

Cell length and width differed significantly among reservoirs $(\mathrm{df}=20, \mathrm{~F}=35.99, p=0.0004$; $\mathrm{df}=20, \mathrm{~F}=17.79, p=0.003)$ decreasing from the SBR and VIG reservoirs to the IPO Reservoir (Table 2).

\section{DISCUSSION}

The pervasiveness of $C$. furcoides from the Paraná River basin (linked to the Del Plata basin) to Paraíba do Sul River follows the species expected route north, as detailed by Meichtry-de-Zaburlín et al. (2016) and Silva et al. (2018). However, water management strategies that link systems and river basins may exacerbate and further accelerate this species proliferation. We detected the dinoflagellate possibly migrating downstream from one river basin (Paraíba do Sul River) to another (Guandu River) via artificial water diversion, which can easily 
Table 2. Ceratium furcoides measurements of body length and width, expressed as total mean, minimum and maximum values for Santa Branca (SBR), Vigário (VIG) and Ilha dos Pombos (IPO) reservoirs. $\mathrm{N}=30,21$ and 21 , respectively. Medidas de comprimento e largura corporal de Ceratium furcoides expressas pelos valores médio, mínimo e máximo para os reservatórios de Santa Branca (SBR), Vigário (VIG) e Ilha dos Pombos (IPO). $N=30,21$ e 21, respectivamente.

\begin{tabular}{cccc}
\hline Length $(\mu \mathrm{m})$ & mean & minimum & maximum \\
\hline SBR & 178 & 149 & 208 \\
VIG & 197 & 174 & 214 \\
IPO & 62 & 51 & 68 \\
\hline Width $(\mu \mathrm{m})$ & mean & minimum & maximum \\
\hline SBR & 50 & 44 & 57 \\
VIG & 43 & 33 & 55 \\
IPO & 16 & 14 & 18 \\
\hline
\end{tabular}

facilitate the spread of non-native species by the connecting hydrographic basins (Anderson et al., 2006; Zhan et al., 2015; Daga et al., 2020). Likewise, Nishimura et al. (2015) previously reported the migration of $C$. furcoides from one reservoir to another (Billings to Guarapiranga Reservoir, Paraná River Basin) as a result of the artificial management of water for domestic supply. Moreno-Ostos et al. (2007) also reported the downstream transfer of $C$. hirundinella by way of a system of reservoirs. The most extensive invasion of $C$. furcoides resulting from water transfers was recently reported in northeastern Brazil where water from the São Francisco Basin was diverted to a northern river basin. Ceratium furcoides drifted via water transposition along the total stretch of waterway and then coursed into associated reservoirs (Mendes et al., 2018).

By herein updating new records of this pervasive dinoflagellate within tropical freshwaters (Silva et al., 2018; Roriz et al., 2019), we provided a snapshot of simultaneous occurrence in three long-distant interconnected reservoirs. Within the present study, C. furcoides proved to be more prevalent in the SBR Reservoir, being ever present in the winter months of 2011 and 2013 and, again in the summer of 2014. It was not the case that $C$. furcoides spread throughout this entire system, being only recorded afar from the dam (Fig. 1), thus, in agreement with the studies of Cassol et al. (2014) and Silva et al. (2012) who discovered that in other tropical reservoirs, the highest cell concentrations were located as distance increased from the dam. Spatial variability in nutrient distribution within reservoirs appear to be related to the presence and abundance of Ceratium. Meichtry-de-Zaburlín et al. (2014) in Yacyretá Reservoir (Argentina-Paraguay) and Roriz et al. (2019) in Paranoá Reservoir (Midwest Brazil) verified a greater abundance of $C$. furcoides nearer to tributaries, feeding off nutrient inputs from human activities such as urbanization, agriculture and industry. The low densities and no evidence of blooms (Table 1) were comparable to the results of Nishimura et al. (2015) in the Billings Reservoir.

The unique occurrence of $C$. furcoides in the winter of 2011 in the VIG and IPO suggests the nomadic nature of this species in such systems that provide favorable mesotrophic conditions but a low water retention time. By right, typical large-celled organisms such as Ceratium with a long cell cycle and low rate of cell division (Bellinger \& Sigee, 2010), should not find suitability in environments with low water retention time. The influence of this hydrological variable on $C$. furcoides was reported by Cassol et al. (2017) in the Itaúba Reservoir in southern Brazil. According to the authors, an increase in retention time favored the proliferation of this species.

Despite the possible limitations as mentioned above, the low mean abundance (26-63 ind $/ \mathrm{mL}$ ) found in the three reservoirs (Table 1) were comparable to those previously reported in other South American tropical mesotrophic reservoirs. In the first record from the Furnas Reservoir, as reported by Santos-Wisniewski et al. (2007), the species attained a maximum mean density of 12 $\mathrm{ind} / \mathrm{mL}$ and following up some years after, within the very same reservoir Silva et al. (2012) recorded mean density up to $28 \mathrm{ind} / \mathrm{mL}$. In the Paranoá Reservoir, Roriz et al. (2019) documented abundances between 6 and $45 \mathrm{ind} / \mathrm{mL}$. Greater abundances (between 62-103 ind $/ \mathrm{mL}$ ) were reported by Bustamante-Gil et al. (2012) in the reservoir Riogrande II, Colombia, and by Silva et al. (2018) (39-137 ind/mL) in the João Leite Reservoir, Midwest Brazil. Conditions of bloom 
( $>1000 \mathrm{ind} / \mathrm{mL}$ ) was reported by Matsumura-Tundisi et al. (2010) in the Billings Reservoir during the winter (21 $455 \mathrm{ind} / \mathrm{mL})$, and by Silva et al. (2018) in the Corumbá Reservoir (up to $2050 \mathrm{ind} / \mathrm{mL}$ ). Blooms were also discovered in South-American sub-tropical reservoirs such as in the eutrophic Maestra Reservoir (2680 ind $/ \mathrm{mL}$ ) and in the meso-eutrophic Faxinal Reservoir (2819 ind $/ \mathrm{mL}$ ) by Cavalcante et al. (2016), and in the Itaúba Reservoir (up to $2036 \mathrm{ind} / \mathrm{mL}$ ) by Cassol et al. (2014).

Spreading of $C$. furcoides in South American reservoirs have been linked to several factors. Proliferation of $C$. furcoides have been broadly associated to: the increase of nutrient content (Silva et al., 2012; Bustamante-Gil et al., 2012; Meichtry-de-Zaburlín et al., 2014; Morales, 2016; Crosseti et al., 2019), water column stability (Bustamante-Gil et al., 2012; Meichtry-de-Zaburlín et al., 2014;), a combination of optimal conditions of temperature (up to $25^{\circ} \mathrm{C}$ ), organic matter, and pH (Cavalcante et al., 2016; Cassol et al., 2017), high dissolved oxygen (Roriz et al., 2019). The eurytopic features were again evident by the presence of warm water in the SBR Reservoir $\left(30.2{ }^{\circ} \mathrm{C}\right)$, and by the wide ranging variability in environmental conditions in which this species appeared to thrive within the three reservoirs (Table 1).

Whilst possessing vertical migration ability, which is an important adaptive behavior for nutrient intake through varying layers of the water column, $C$. furcoides presents several features that go somehow in explaining its proliferation. The cyst formation (Pollingher, 1988), which is a result of sexual reproduction (Hickel, 1988) also increases dispersion rates of Ceratium (Donagh et al., 2005). Phagotrophic ability and mixotrophic nutrition, plus the development of horns (proposed defensive structures) all contribute to lowering grazing pressure by zooplankton (Ginkel et al., 2005). Furthermore, morphological plasticity can likewise be related to eurytopic features. Variation in size of $C$. furcoides over periods of time have already been detected in South American reservoirs, this such as seasonal cell-size variation (Cavalcante et al., 2018; Roriz et al., 2019) and smaller individuals (length between 118-315 $\mu \mathrm{m}$ ) during blooms (Almanza et al.,
2016). The broad morphometric variation in Ceratium has been considered an adaptive trait for environmental filtering, especially when dealing with changes in water temperature (Lindström, 1992; Cavalcante et al., 2016), but also the case with biotic pressures (e.g. herbivory) and resistance to mechanical damage (Bertolo et al., 2010). In addition to variation in size, $C$. furcoides morphological plasticity can also be related to variation in the number of horns (the third atypical horn identified as being in the first stages in figure 2 ), this generally associated to seasonal environmental changes and abundance of the population (Lindström, 1992; Almanza et al., 2016).

Size and form selection are perhaps the strongest driving forces shaping phytoplankton assemblages under variable environmental conditions (Morabito et al., 2007). Dynamic aquatic environments support a large diversity of different sizes and shapes of species either present in the assemblages or as propagules "ready to develop' as the environmental template changes (Padisák, 1992). The difference in C. furcoides cell size across the reservoirs reported in this study might be related to adaptation to water current, as smaller individuals were found in the IPO Reservoir. This more hydrodynamic and eutrophic system presented the smaller cell sizes (length between 51-68 $\mu \mathrm{m}$ ), not only comparable to the SBR and VIG reservoirs but overall in similar data available within the literature of Brazilian freshwaters (Oliveira et al., 2011; Cassol et al., 2014; Moreira et al., 2015). Considering the short retention time of the IPO reservoir ( 0.2 days), it can be suggested that the dinoflagellate population primarily venture from the Paraíba do Sul River. Being of small size, in tandem with an adaptation to mechanical damage due to water current, could well be a resource-saving strategy to population maintenance and propagule density increase until arriving at a more favorable environment (Hutchinson, 1967; Raven, 1998; Cavalcante et al., 2016; Sharma \& Rai, 2011). Moreover, under a river-flowing condition, size may not prove an important factor in avoiding predation.

Blooms of Ceratium species have been directly related to multiple negative effects ranging from fish-kill through gill clogging and oxygen 
depletion in the water column (Smayda, 1997; Matsumura-Tundisi et al., 2010) to foul-tasting and odor in drinking waters (Ewerts et al., 2013). This scenario requires concern on a regional scale as both economic activity and the domestic water supply for millions of people depend on these river systems. The extensive monitoring of eutrophic reservoirs within this system, e.g. the Funil Reservoir in Paraiba do Sul mainstream, must have non-detection status upgraded and currently revised, this should include an improvement in sampling techniques by deep sampling resulting from Ceratium ability to migrate into the water column. Furthermore, within this context of effective monitoring, fluctuations in trophic and hydrological conditions or, in retention time due to expected rainfall variation - the result of climate change - presents a possible "window of opportunity" for populations of $C$. furcoides to further proliferate (Matsumura-Tundisi et al., 2010; Crosseti et al., 2019). In view of the fact that these reservoirs are included in monitoring programs overseen by environmental control agencies, in the recognition of multi-purpose priority of these waters (CETESB, 2020; INEA, 2020), this presents as a recent invasion. However, up until this point in time, there is no occurrence of Ceratium bloom.

\section{CONCLUSION}

Herein, more than solely documenting for the first time the expansion of the dinoflagellate Ceratium furcoides within two economically important river basins in Brazil's Paraiba do Sul ecoregion, our study additionally highlights the importance of monitoring tropical systems greatly impacted by human activity from which can further enhance the risk of biological invasion (Johnson et al., 2008). From scrutinizing the eurytopic features and dispersal ability of $C$. furcoides, we can forecast that other nearby systems throughout Paraíba do Sul and Guandu river basins, including reservoirs and small lakes are potential grounds for the proliferation of $C$. furcoides. Future studies are recommended to focus on the relationships among C. furcoides populations features in Brazilian reservoirs, in order to understand the expansion success of this species.

\section{ACKNOWLEDGEMENTS}

We thank CAPES foundation (Science without Borders Program/Special Visiting Professor PVE Project n ${ }^{\circ} 88887.093228 / 2015-00$ coordinated by CWCB), the Research \& Development Program of Light Energy Company (Estocagem de Carbono, Nitrogênio e Fósforo em Reservatórios da Light Energia Project), the Fundo Brasileiro para a Biodiversidade (FUNBIO, postdoc grant to ACSF) and FURNAS Centrais Elétricas S.A. for financial support. We are grateful for the support of PIBIC/CNPq and PIBITI scholarships from the Federal University of the State of Rio de Janeiro (Edital INOVA-2018/UNIRIO) for KNC, RFC and MGRT. We also thank PR Vitorino and LC Souza, for multiple assistances including laboratory analysis and fieldwork. We especially thank Sara Teixeira de Macedo Silva and Vânia da Silva Vieira for the support in electron microscope analysis at Federal University of Rio de Janeiro.

\section{REFERENCES}

ALMANZA, V., C. E. D. M. BICUDO, O. PARRA \& R. URRUTIA. 2016. Características morfológicas y limnológicas de las floraciones de Ceratium furcoides (Dinophyta) en un lago somero de Chile Central. Limnetica, 35 (1): 253-268. DOI: 10.23818/limn.35.21

ANDERSON, E. P., M. C. FREEMAN, \& C. M. PRINGLE. 2006. Ecological Consequences of Hydropower Development in Central America: Impacts of Small Dams and Water Diversion on Neotropical Stream Fish Assemblages. River Research and Application, 22 (4): 397-411. DOI: 10.1002/rra.899

ANDERSON, E. P., C. N. JENKINS, S. HEILPERN, J. A. MALDONADO-OCAMPO, F. M. CARVAJAL-VALLEJOS, A. C. ENCALADA, J. F. RIVADENEIRA, M. HIDALGO, C. M. CAÑAS, H. ORTEGA, N. SALCEDO, M. MALDONADO \& P. A. TEDESCO. 2018. Fragmentation of Andes-toAmazon connectivity by hydropower dams. Science Advances, 4 (1): 1-8. DOI: 10.1126/ sciadv.aao 1642

APHA. 2005. Standard Methods for the Examination of Water and Wastewater. American 
Public Health Association, Washington D.C. BELLINGER E. G. \& D. C. SIGEE. 2010. Freshwater Algae: identification and use as bioindicators. Wiley-Blackwell, Chichester, UK. DOI: $10.1007 / \mathrm{s} 10811-012-9926-\mathrm{X}$

BERTOLO, A., G. LACROIX, F. LESCHERMOUTOUÉ \& J. HJELM. 2010. Relationship between fish and the number of horns in Ceratium hirundinella (Dinophyceae): a food-webmediated effect on algal morphology? Journal of Phycology, 46: 33-40. DOI: 10.1111/j.15298817.2009.00775.x

BOLTOVSKOY, A., ECHENIQUE, R., J. M. GUERRERO. 2013. Sucesivas invasiones de especies de Ceratium (Dinophyceae) en Sudamérica: un proceso que lleva dos décadas. Boletín de la Sociedad Argentina de Botánica, 48:27.

BRANCO, C. W. C., J. J. F. LEAL, V. L. de M. HUSZAR, D. da S. FARIAS, T. D. SAINT'PIERRE, I. F. SOUSA-FILHO, E. F. de A. DE PALERMO, A. W. S. GUARINO, A. R. GOMES \& B. KOZLOWSKY-SUZUKI. 2019. New lake in a changing world: the construction and filling of a small hydropower reservoir in the tropics (Rio de Janeiro, Brazil). Environmental Science and Pollution Research, 26: 36007-36022. DOI: 10.1007/ s11356-019-06665-y

BUSTAMANTE GIL, C., J. J. RAMÍREZ RESTREPO, A. BOLTOVSKOY \& A. VALLEJO. 2012. Spatial and temporal change characterization of Ceratium furcoides (Dinophyta) in the equatorial reservoir Riogrande II, Colombia. Acta Limnologica Brasiliensia, 24 (2): 207-219. DOI: 10.1590/ S2179-975X2012005000039

CASSOL, A. P. V., W. PEREIRA FILHO, M. A. OLIVEIRA, A. L. DOMINGUES, F. S. CORREA \& G. A. BURIOL. 2014. First record of a bloom of the invasive species Ceratium furcoides (Levander) Langhans 1925 in Rio Grande do Sul state, Brazil. Brazilian Journal of Biology, 74(2): 515-517. DOI: 10.1590/1519-6984.05413

CASSOL, A. P. V., M. A. OLIVEIRA, A. L. DOMINGUES, W. PEREIRA-FILHO, M. DURIGON \& J. F. da SILVA. 2017. Climate factors and limnological conditions shaping phytoplankton community in two subtropical cascading reservoirs. Acta Limnologica Brasiliensia, 29: e17. DOI: 10.1590/s2179-975x6316 CAVALCANTE, K. P., J. C. ZANOTELLI, C. C. MÜLLER, K. D. SCHERER, J. K. FRIZZO, T. A. V. LUDWIG \& L. D. S. CARDO. 2013. First record of expansive Ceratium Schrank, 1793 species (Dinophyceae) in Southern Brazil, with notes on their dispersive patterns in Brazilian environments. Check List, 9 (4): 862-866. DOI: 10.1111/1re.12211

CAVALCANTE, K. P., L. de S. CARDOSO, R. SUSSELLA \& V. BECKER. 2016. Towards a comprehension of Ceratium (Dinophyceae) invasion in Brazilian freshwaters: autecology of $C$. furcoides in subtropical reservoirs. Hydrobiologia, 771 (1): 265-280. DOI: 10.1007/s10750-015-2638-x

CAVALCANTE, K. P., V. BECKER \& L. de S. CARDOSO. 2018. A proxy for estimating the cell volume of Ceratium furcoides (Dinophyceae): basis for monitoring Brazilian reservoirs. Lakes and Reservoirs: Research and Management, 23 (2): 168-171. DOI: 10.1111/ lre. 12211

CEIVAP, 2020. Comitê de Integração da Bacia Hidrográfica do Rio Paraíba do Sul (Paraíba do Sul River Basin Integration Committee). General data. https://www.ceivap.org.br/dadosgerais.php (accessed on 4th January 2020)

COSTA, P. R., J. C. MARTINS \& P. CHAINHO. 2017. Impact of Biological Invasions on Ecosystem Services. Invading Nature Springer Series in Invasion Ecology. M.Vilà, P. Hulme (ed.): 221-234. Springer International Publishing.

CROSSETTI, L. O., D. DE C. BICUDO, L. M. BINI, R. B. DALA-CORTE, C. FERRAGUT \& C. E. DE MATTOS BICUDO. 2018. Phytoplankton species interactions and invasion by Ceratium furcoides are influenced by extreme drought and water-hyacinth removal in a shallow tropical reservoir. Hydrobiologia, 831 (1): 71-85. DOI: 10.1007/s10750-0183607-y

DARKI, B. Z. \& A. F. KRAKHMALNYI. 2019. Biotic and abiotic factors affecting the population dynamics of Ceratium hirundinella, Peridinium cinctum, and Peridiniopsis 
elpatiewskyi. Diversity, 11 (8): 137. DOI: 10.3390/d11080137

DE OLIVEIRA, H. S. B., A. do N. MOURA \& M. K. CORDEIRO-ARAÚJO. 2011. First record of Ceratium Schrank, 1973 (Dinophyceae: Ceratiaceae) in freshwater ecosystems in the semiarid region of Brazil. Check List, 7 (5): 626-628. DOI: 10.15560/7.5.626

DODSON S. I. \& D. G. FREY. 2001. Cladocera and other Branchiopoda. In: Ecology and Classification of North American Freshwater Invertebrates. Thorp J. H., Covich A.P. (eds): 850-914. Academic Press, San Diego.

DUDGEON, D., A. H. ARTHINGTON, M. O. GESSNER, Z. I. KAWABATA, D. J. KNOWLER, C. LÉVÊQUE, R. J. NAIMAN, A. H. PRIEUR-RICHARD, D. SOTO, M. L. J. STIASSNY \& C. A. SULLIVAN. 2006. Freshwater biodiversity: Importance, threats, status and conservation challenges. Biological Reviews of the Cambridge Philosophical Society, 81 (2): 163-182. DOI: 10.1017/ S1464793105006950

ESTEVES, F. A. 2011. Gênese dos ecossistemas lacustres. In: Fundamentos de Limnologia. Editora Interciência $3^{\mathrm{a}}$ ed (ed): 83-112pp. Rio de Janeiro. Brasil.

EWERTS, H. E., A. SWANAPOEL \& H. H. du PREEZ. 2013. Efficacy of conventional drinking water treatment processes in removing problem-causing phytoplankton and associated organic compounds. Water SA, 39 (5): 739-750. DOI: $10.4314 /$ wsa.v39i5.19

FREEMAN M. C., C. M. PRINGLE \& C. R. JACKSON. 2007. Hydrologic Connectivity and the Contribution of Stream Headwaters to Ecological Integrity at Regional Scales. Journal of the American Water Resources Association, 43 (1): 5-14. DOI: 10.1111/j.1752-1688. 2007.00002.x

GAZONATO-NETO, A. J. 2013. Estudo limnológico dos reservatórios Jaguari e Jacareí com ênfase na comunidade zooplanctônica. Dissertação de Mestrado (Ecologia e Recursos Naturais), Universidade Federal de São Carlos, São Carlos.

GENITSARIS S., K. A. KORMAS, M. MOUSTAKA-GOUNI. 2011. Airborne Algae and Cyanobacteria: Occurrence and Related
Health Effects. Frontiers in Bioscience, 3(2):772-87. DOI: $10.2741 / \mathrm{e} 285$

HAVEL J. E. \& J. B. SHURIN. 2004. Mechanisms, effects, and scales of dispersal in freshwater zooplankton. Limnology and Oceanography, 49 (4): 1229-1238. DOI: 10.4319/lo. 2004.49.4_part_2.1229

HAVEL, J. E., C. E. LEE \& M. J. VANDER ZANDEN. 2005a. Do reservoirs facilitate invasions into landscapes? BioScience, 55(6): 518-525. DOI: 10.1641/0006-3568(2005)055 [0518:DRFIIL]2.0.CO;2

HICKEL, B. 1988. Sexual reproduction and life cycle of Ceratium furcoides (Dinophyceae) in situ in the lake Plußsee (F.R.). Hydrobiologia, 161: 41-48. DOI: 10.1007/978-94-009-309713

HUTCHINSON, G. E. 1967. A Treatise on Limnology. II. Introduction to lake Biology and the Limnoplankton. New York: John Wiley and Sons. 1115p. DOI: 10.4319/lo.1969. 14.3.0472

JOHNSON, P. T. J., J. D. OLDEN \& M. J. VANDER ZANDEN. 2008. Dam invaders: Impoundments facilitate biological invasions into freshwaters. Frontiers in Ecology and the Environment, 6 (7): 357-363. DOI: 10.1890/ 070156

LANGHANS, V. H. (1925). Gemischte Populationen von Ceratium hirundella (O.F.M) schrank und ihre Deutung. Archiv für Protistenkunde, 52: 585-602.

LEBRET, K., E. S. KRITZBERG \& K. RENGEFORS. 2013. Population genetic structure of a microalgal species under expansion. PLoS ONE, 8 (12). DOI: 10.1371/journal.pone. 0082510

LIERMANN C. R., C. NILSSON, J. ROBERTSON, R. Y. NG. 2012. Implications of Dam Obstruction for Global Freshwater Fish Diversity. Bioscience, 62 (6):539-548. DOI: 10.1525/bio.2012.62.6.5

LINDSTRÖM, K. 1992. Ceratium in Lake Erken: vertical distribution, migration and form variation. Nordic Journal of Botany, 12 (5): 541-556. DOI: 10.1111/j.1756-1051.1992. tb01833.x

LITVINCHUK, L. F., I. K. RIVIER \& V. E. PANOV. 2001. Dynamics of abundance, 
structure of population and fecundity of Ponto-Caspian cladoceran, Cercopagis pengoi (Ostroumov, 1891)(Polyphemoidea, Cercopagidae) in the eastern Gulf of Finland, the Baltic Sea. Biology of Inland Waters, 1: 57-62. LUND, J. W. G., C. KIPLING \& E. D. LE CREN. 1958. The inverted microscope method of estimating algal number and the statistical basis of estimating by counting. Hydrobiologia, 11: 143-170. DOI: 10.1007/BF00007865

MAC DONAGH, M. E., M. A. CASCO \& M. C. CLAPS. 2005. Colonization of a neotropical reservoir (Córdoba, Argentina) by Ceratium hirundinella (O. F. Müller) Bergh. International Journal of Limnology, 41 (4): 291-299. DOI: $10.1051 / \mathrm{limn} / 2005020$

MATSUMURA-TUNDISI, T., J. G. TUNDISI, A. P. LUZIA \& R. M. DEGANI. 2010. Occurrence of Ceratium furcoides (Levander) Langhans 1925 bloom at the Billings Reservoir, São Paulo State, Brazil. Brazilian Journal of Biology, 70 (3): 825-829. DOI: 10.1590/S151969842010000400013

MEICHTRY-DE-ZABURLÍN, N. M., A. BOLTOVSKOY, C. C. ROJAS \& R. M. RODRIGUEZ. 2014. Primer registro del dinoflagelado invasor Ceratium furcoides (Levander) Langhans 1925 en la Argentina y su distribución en el área de influencia del Embalse Yacyretá (río Paraná, Argentina-Paraguay). Limnetica, 33 (1): 153-160. DOI: 10.23818/limn.33.12

MEICHTRY-DE-ZABURLÍN, N. M., R. E. VOGLER, M. J. MOLINA \& V. M. LLANO. 2016. Potential distribution of the invasive freshwater dinoflagellate Ceratium furcoides (Levander) Langhans (Dinophyta) in South America. Journal of Phycology, 52: 200-208. DOI: $10.1111 /$ jpy.12382

MENDES, C. F., L. M. FERREIRA, F. M. MONTEIRO, J. S. SEVERIANO \& J. E. L. BARBOSA. 2018. Análise da dispersão de Ceratium furcoides (Levander) Langhans $1925 \mathrm{em}$ reservatórios tropicais do nordeste brasileiro. Associação brasileira de recursos hídricos. XIV Simpósio de recursos hídricos do Nordeste.

MOESTRUP, Ø. \& A. J. CALADO. 2018. Süßwasserflora von Mitteleuropa. Freshwater Flora of Central Europe, Volume 6: Dinophyceae. Springer Spektrum, Berlin.
MORABITO, G., A. OGGIONI, E. CARAVATI \& P. PANZANI. 2007. Seasonal morphological plasticity of phytoplankton in Lago Maggiore (N. Italy). Hydrobiologia, 578: 47-57. DOI: 10.1590/1519-6984.08013

MORALES, E. A. 2016. Floración de Ceratium furcoides (Levander) Langhans (Dinoflagellata, Dinophyceae) en la represa de La Angostura, Cochabamba, Bolivia. Acta Nova (On-line), 7 (4): 389-398. ISSN 1683-0789

MOREIRA, R. A., O. ROCHA, R. M. SANTOS, R. LAUDARES-SILVA, E. S. DIAS \& E. M. ESKINAZI-SANT'ANNA. 2015. First record of Ceratium furcoides (Dinophyta), an invasive species, in a temporary high-altitude lake in the Iron Quadrangle (MG, Southeast Brazil). Brazilian Journal of Biology, 75 (1): 98-103. DOI: 10.1590/1519-6984.08013

MORENO-OSTOS, E., J. A. ELLIOTT, L. CRUZ-PIZARRO, C. ESCOT, A. BASANTA \& D. G. GEORGE. 2007. Using a numerical model (PROTECH) to examine the impact of water transfers on phytoplankton dynamics in a Mediterranean reservoir. Limnetica, 26(1): 1-11. DOI: 10.23818/limn.26.01

NISHIMURA, P. Y; M. POMPÊO \& V. MOSCHINI-CARLOS. 2015. Invasive dinoflagellate Ceratium furcoides (Levander) Langhans in two linked tropical reservoirs. In: Ecologia de reservatórios e interfaces, São Paulo. Pompêo et al. (Orgs): 132-142. Instituto de Biociências da Universidade de São Paulo.

NUNES, A. L., J. M. FILL, S. J. DAVIES, M. LOUW, A. D. REBELO, C. J. THORP, G. VIMERCATI \& J. MEASEY. 2019. A global meta-analysis of the ecological impacts of alien species on native amphibians. Proceedings of the Royal Society B: Biological Sciences, 286 (1897).

NUSCH, E. A. \& G. PALME. 1975. Biologische Methoden für die Praxis der Gewässeruntersuchung. GWF-Wasser/Abwasser, 116: 562-565.

PADISÁK, J. 1992. Seasonal succession of phytoplankton in a large shallow lake (Balaton, Hungary) - a dynamic approach to ecological memory, its possible role and mechanisms. Journal of Ecology, 80: 217-230. DOI: $10.2307 / 2261008$

PEREIRA, L. S, R de A. F. NEVES, I. C. MIYA- 
HIR, B. KOZLOWSKY-SUZUKI, C. W. C. BRANCO, J. C. de PAULA et al., 2018. Non-native species in reservoirs: how are we doing in Brazil? Hydrobiologia, 817: 71-84. DOI: $10.1007 / \mathrm{s} 10750-017-3446-2$

POLLINGHER, U. 1988. Freshwater armored dinoflagellates: Growth, reproduction, strategies, and population dynamics. In: Growth and reproductive strategies of freshwater phytoplankton. Cambridge: Cambridge University Press. C. D SANDGREN (ed): 134-174 pp.

RAMIREZ-R., J. J., F. L. GUTIERREZ \& A. VARGAS. 2005. Phytoplankton community response to artificial eutrophication experiments conducted in the $\mathrm{La} \mathrm{Fe}$ reservoir, El Retiro, Antioquia, Colombia. Caldasia [online], vol.27, n.1, pp.103-115. ISSN 0366-5232.

RAVEN, J. A. 1998. The twelfth Tansley Lecture. Small is beautiful: the picophytoplankton. Functional Ecology, 12: 503-513. DOI: 10.1046/j.1365-2435.1998.00233.x

REID, A. J., A. K. CARLSON, I. F. CREED, E. J. ELIASON, P. A. GELL, P. T. J. JOHNSON, K. A. KIDD, T. J. MACCORMACK, J. D. OLDEN, S. J. ORMEROD, J. P. SMOL, W. W. TAYLOR, K. TOCKNER, J. C. VERMAIRE, D. DUDGEON \& S. J. COOKE. 2019. Emerging threats and persistent conservation challenges for freshwater biodiversity. Biological Reviews, 94 (3): 849-873. DOI: 10.1111/brv. 12480

ROCHA, O. \& A. DUNCAN. 1985. The relationship between cell carbon and cell volumein freshwater algal species used in zooplanktonic studies. Journal of Plankton Research, 7 (2): 279-294. DOI: 10.1093/plankt/7.2.279

RORIZ, P. R. C., B. D. BATISTA \& B. M. FONSECA. 2019. First record of the invasive species Ceratium furcoides (Levander) langhans 1925 (dinophyceae) in lake Paranoá, Federal District. Oecologia Australis, 23 (3): 620-635. DOI: 10.4257/oeco.2019.2303.18

SANTOS-WISNIEWSKI, M. J., L. C. SILVA, I. C. LEONE, R. LAUDARES-SILVA \& O. ROCHA. 2007. First record of the occurrence of Ceratium furcoides (Levander) Langhans 1925, an invasive species in the hydroelectricity power plant Furnas Reservoir, MG, Brazil.
Brazilian Journal of Biology, 67 (4): 791-793. DOI: $10.1590 / \mathrm{S} 1519-69842007000400033$

SAX, D. F. 2001. Latitudinal gradients and geographic ranges of exotic species : implications for biogeography. Journal of Biogeography, 28 (1): 139-150. DOI: 10.1046/j.13652699.2001.00536.x

SHARMA, N. K., A. K. RAI. 2011. Biodiversity and biogeography of microalgae: progress and pitfalls, Environmental Reviews, vol. 19 (pg. 1-15). DOI: 10.1139/a10-020

SHURIN, J. B. 2000. Dispersal limitation, invasion resistance and the structure of pond zooplankton communities. Ecology, 81(11): 3074-3086. DOI: 10.2307/177402

SILVA, L.C., I. C. LEONE, M. J. dos SANTOS-WISNIEWSKI, A. C. PERET \& O. ROCHA. 2012. Invasion of the dinoflagellate Ceratium furcoides (Levander) Langhans 1925 at tropical reservoir and its relation to environmental variables. Biota Neotropica, 12 (2): 93-100. DOI: 10.1590/S1676-06032012000200010

SILVA, W. J., I. de S. NOGUEIRA, E. M. de MELO-MAGALHÃES, S. H. M. BENÍCIO, S. M. PESSOA \& M. MENEZES. 2018. Expansion of invasive Ceratium furcoides (Dinophyta) toward north-central brazil: New records in tropical environments. Acta Limnologica Brasiliensia, 30: e210. DOI: 10.1590/s2179-975x5917

SMAYDA, T. J. 1997. What is a bloom? A commentary. Limnology and Oceanography, 42 (5): 1132-1136. DOI: 10.4319/1o.1997.42. 5 part 2.1132

TOLEDO, A. P. J., M. TALARICO, S. J. CHINEZ \& E. G. AGUDO. 1983. A aplicação de modelos simplificados para a avaliação de processo de eutrofização em lagos e reservatórios tropicais. Anais do $12^{\circ}$ Congresso de Engenharia Sanitária e Ambiental. Camboriú.

UNEP. 2010. State of Biodiversity in Latin America and the Caribbean. Available from http://www.unep.org/delc/Portals/119/ Latinmerica_StateofBiodiv.pdf.

UTERMOHL, $\bar{H}$. 1958. Zur Vervollkommung der quantitative Phytoplankton -Methodik. Internationale Vereinigung für Theoretische und Angewandte Limnologie: Mitteilungen, 9 (1): 
1-38. DOI: 10.1080/05384680.1958.11904091 VAN GINKEL, C. E., B. C. HOHLS \& E. VERMAAK. 2001. A Ceratium hirundinella (O.F. Müller) bloom in Hartbeespoort Dam, South Africa. Water SA, 27 (2): 269-276. DOI: 10.4314/wsa.v27i2.5000

XIONG W., H. WANG, Q. WANG, J. TANG, P. A. BOWLER, D. XIE, L. PANPAN, Z. WANG. 2018. Non-native species in the
Three Gorges Dam Reservoir: status and risks. BioInvasions Records, 7 (2): 153- 158. DOI: 10.3391/bir.2018.7.2.06

ZHAN, A., L. ZHANG, Z. XIA, P. NI, W. XIONG, Y. CHEN, G. D. HAFFNER \& H. J. MACISAAC. 2015. Water diversions facilitate spread of non-native species. Biological Invasions, 17 (11): 3073-3080. DOI: 10.1007/ s10530-015-0940-1 